\title{
Kekuatan Pembuktian Akta Notaris yang Dibuat oleh Notaris yang Sedang Diusulkan untuk Diberhentikan dengan Tidak Hormat
}

\author{
Selly Yashinta Theresa Laseduw \\ chellylaseduw@yahoo.com \\ Universitas Airlangga
}

\begin{abstract}
The notary institution is an institution that is needed by the community in making evidence for them in the form of authentic deeds. Notary profession is a position of trust that is responsible. However, in the field in the practice of a notary there are many violations that occur, as is the case that ensnared one of the Notaries in Central Kalimantan, where the AP Notary and Masdundung and AT made an illegal notary deed. In this case the AP Notary was sentenced to Article 266 paragraph (1) jo. Article 55 paragraph (1) of the Criminal Code, in UUJN and the Notary Notary Ethics Code of AP has violated Article 16 paragraph (1) letter a UUJN. Regarding the violations made by the AP, he must be personally responsible and issued a decree from the Central Supervisory Board, namely regarding the proposal of giving sanctions for dismissal with no respect to the Minister of Law and Human Rights of the Republic of Indonesia. The problem arises when the AP that has received a proposal for a dismissal is not respectful but still continues to carry out its office activities.
\end{abstract}

Keywords: Notary; Proposed; Dismissed; Disrespectful.

\begin{abstract}
Abstrak
Lembaga notariat merupakan suatu lembaga yang dibutuhkan masyarakat dalam pembuatan alat bukti bagi mereka yaitu berupa akta otentik. Profesi Notaris merupakan suatu jabatan kepercayaan yang bertanggung jawab. Namun demikian dilapangan dalam praktek seorang notaris terdapat bnyak pelanggaran yang terjadi, sebagaimana kasus yang menjerat salah satu Notaris di Kalimantan Tengah, dimana Notaris AP serta Masdundung dan AT melakukan pembuatan akta notaris illegal. Dalam kasus ini Notaris AP dijatuhkan Pidana Pasal 266 ayat (1) jo. Pasal 55 ayat (1) Kitab Undang-undang Hukum Pidana, secara UUJN dan Kode Etik Notaris Notaris AP telah melanggar Pasal 16 ayat (1) huruf a UUJN. Terhadap pelanggaran tersebut yang dibuat oleh AP, ia harus bertanggung jawab secara pribadi dan dikeluarkan surat keputusan dari Majelis Pengawas Pusat yakni perihal usulan pemberian sanksi pemberhentian dengan tidak hormat kepada Menteri Hukum dan Hak Asasi Manusia Republik Indonesia. Timbul Persoalan ketika AP yang sudah mendapat surat usulan pemberhentian dengan tidak hormat namun tetap masih menjalankan aktifitas kantornya.
\end{abstract}

Kata Kunci: Notaris; Diusulkan; Diberhentikan; Tidak Hormat.

\section{Pendahuluan}

Kebutuhan akan jasa Notaris saat ini begitu besar dalam mendukung berbagai pelaksanaan kegiatan dalam bidang keperdataan. Pasal 1 ayat (1) Undang-Undang Nomor 2 Tahun 2014 tentang Perubahan Atas Undang-Undang Nomor 30 Tahun 2004 tentang Jabatan Notaris (selanjutnya akan ditulis UUJN) menyebutkan bahwa Notaris adalah pejabat umum yang berwenang untuk membuat akta otentik 
dan memiliki kewenangan lainnya sebagaimana dimaksud dalam undang-undang ini atau berdasarkan undang-undang lainnya. Sedangkan dalam Kode Etik Notaris, yang dimaksud Notaris adalah setiap orang yang memangku dan menjalankan tugas jabatan sebagai pejabat umum, sebagaimana yang dimaksud dalam Undang-undang tentang Jabatan Notaris.

Meningkatnya kebutuhan akan jasa Notaris membuat profesi Notaris ini semakin penting, hal ini didukung dengan adanya keberadaan peraturan perundangundangan dalam bidang Kenotariatan yang diharapkan dapat memberikan peran dalam asosiasi profesi Notaris. Pada dasarnya lembaga notariat merupakan salah satu lembaga dalam masyarakat yang timbul karena kebutuhan dalam pergaulan, yang menghendaki adanya alat bukti hukum bagi mereka. ${ }^{1}$ Oleh karena lembaga notariat merupakan suatu lembaga yang dibutuhkan masyarakat dalam pembuatan alat bukti bagi mereka yaitu berupa akta otentik maka disinilah profesi notaris di butuhkan. Profesi Notaris adalah profesi terbuka artinya setiap orang dapat bertahan atau keluar dari profesi tersebut sewaktu - waktu. ${ }^{2}$ Profesi Notaris merupakan suatu jabatan kepercayaan yang bertanggung jawab, dimana Notaris membuat sebuah akta otentik yang merupakan suatu alat bukti yang sempurna sesuai dengan Pasal 1868 Burgelijk Wetboek (selanjutnya akan ditulis BW).

Seorang notaris harus bertindak jujur, saksama, mandiri, tidak berpihak, penuh rasa tanggung jawab berdasarkan peraturan perundang-undangan dan isi sumpah jabatan notaris. ${ }^{3}$ Seorang Notaris juga harus menjunjung tinggi harkat dan martabat profesi jabatan Notaris. Namun demikian dilapangan dalam praktek seorang notaris terdapat pelanggaran, sebagaimana kasus yang ada terjadi, yang menjerat salah satu Notaris di Kalimantan Tengah, dimana Notaris AP serta Masdundung dan AT melakukan pembuatan akta notaris illegal. Terungkap bahwa saham mayoritas yang dimiliki HED dan Sulastri dipindahkan tersangka secara illegal sehingga menjadi milik AT bersama Masdundung. Pembuatan akta notaris

\footnotetext{
Abintoro Prakoso, Etika Profesi Hukum (LaksBang Justitia 2015).[135].

ibid.[137].

3 Freddy Haris, Notaris Indonesia (Lintas Cetak Djaja 2017).[39].
} 
pemindahan saham ini dilakukan oleh tersangka notaris AP. Bahwa pemilik saham mayoritas HED saat tersangka memalsukan akta palsu tersebut sudah meninggal dunia dua tahun sebelumnya. Dalam Rapat Umum Pemegang Saham (RUPS) PT AAK tersangka memalsukan tanda tangan dan daftar hadir almarhum seolah olah almarhum hadir saat itu. Diketahui bahwa di areal PT AAK dan PT Anugerah Alam Manuhing (PT AAM) terdapat sumber batu bara, bijih besi dengan deposit dan kualitas yang sangat tinggi. ${ }^{4}$ Karena perbuatan AP yang merugikan orang lain, AP dilaporkan kepada Majelis Pengawas Daerah, dan dilakukan pemeriksaan terhadap AP. Kasus AP bergulir hingga dalam kasus ini Notaris AP dijatuhkan Pidana Pasal 266 ayat (1) jo. Pasal 55 ayat (1) Kitab Undang-undang Hukum Pidana, secara UUJN dan Kode Etik Notaris Notaris AP telah melanggar Pasal 16 ayat (1) huruf a UUJN. Atas pelanggaran tersebut yang dibuat oleh AP, ia harus bertanggung jawab secara pribadi dan dikeluarkan surat keputusan dari Majelis Pengawas Pusat yakni perihal usulan pemberian sanksi pemberhentian dengan tidak hormat kepada Menteri Hukum dan Hak Asasi Manusia Republik Indonesia. Surat usulan pemberian sanksi pemberhentian dengan tidak hormat kepada menteri tersebut diberikan pada AP karena AP melakukan pelanggaran pidana sehingga melalui Pasal 13 UUJN bahwa Notaris diberhentikan dengan tidak hormat oleh Menteri karena dijatuhi pidana penjara berdasarkan putusan pengadilan yang telah memperoleh kekuatan hukum tetap karena melakukan tindak pidana yang diancam dengan pidana penjara 5 (lima) tahun atau lebih. Surat usulan dari Majelis Pengawas Pusat ini dapat diberikan setelah ada putusan akhir dan mengikat. Persoalan timbul ketika AP yang sudah mendapat surat usulan pemberhentian dengan tidak hormat namun tetap masih menjalankan aktifitas kantornya.

Pelaksanaan tugas dan jabatan dari profesi notaris, notaris dituntut untuk menjalankan tugas dengan memperhatikan asas itikad baik dan prinsip kehatihatian, mengingat profesi Notaris merupakan profesi kepercayaan sehingga jangan sampai kesalahan maupun kelalaian yang dilakukan oleh seorang Notaris berujung

\footnotetext{
${ }^{4}$ http://www.borneonews.co.id/berita/26990-inilah-kisah-menyerobot-saham-perusahaan, diunduh pada tanggal 01 Maret 2017, pukul 20.52 WIB (Waktu Indonesia Barat).
} 
pada perbuatan melanggar hukum. Menurut Imelda Mouly Irianty, kurang ketelitian Notaris dalam menjalankan tugas dan wewenangnya melahirkan suatu pepatah yaitu "Ignorantia Notarium, Panis Advocatorium" yang artinya adalah "Kebodohan daripada Notaris adalah pencaharian (roti) bagi para pengacara". 5

Berdasarkan uraian diatas, menarik untuk dibahas dan dikaji lebih dalam mengenai kewenangan notaris dalam membuat akta setelah diusulkan untuk diberhentikan dengan tidak hormat dan mengenai tanggung jawab Notaris terhadap akta yang dibuat oleh dan dihadapannya setelah diusulkan diberhentikan dengan tidak hormat dalam pembuatan akta.

\section{Kewenangan notaris dalam membuat akta setelah diusulkan untuk diberhentikan dengan tidak hormat}

Kewenangan adalah suatu kekuasaan untuk membuat keputusan untuk memerintahkan atau melimpahkan tanggung jawab kepada orang lain. Kewenangan merupakan hak seorang individu untuk melakukan suatu tindakantindakan tertentu dengan batasan-batasan tertentu yang mana tindakan tersebut diakui oleh individu lain. ${ }^{6}$

Notaris adalah profesi dan juga sebagai pejabat umum. Kewenangan pejabat umum diperoleh langsung dari kekuasaan tertinggi yaitu negara, ${ }^{7}$ maka dari itu dalam menjalankan jabatannya, seorang Notaris menerima kewenangan berdasarkan undang-undang, sebagaimana disebutkan dalam Pasal 1868 BW dan Pasal 1 UUJN, kewenangan yang diperoleh oleh notaris termasuk pada sumber kewenangan atribusi. Berdasarkan UUJN tersebut, notaris adalah pejabat publik yang mendapat wewenang secara atribusi, karena wewenang tersebut diciptakan dan diberikan oleh UUJN tersebut. ${ }^{8}$

\footnotetext{
5 Imelda Mouly Irianty, Tinjauan Yuridis Mengenai Notaris Yang Cuti Diangkat Sebagai Pejabat Negara (Tesis, Magister Kenotariatan Universitas Indonesia 2010).[50].

${ }^{6}$ Ridwan HR, Hukum Administrasi Negara (Raja Grafindo Persada 2006).[105].

7 Freddy Haris, Notaris Indonesia ( Jakarta 2017).[45].

${ }^{8}$ M. Luthfan Hadi arus, Hukum Notariat Dan Tanggungjawab JABATAN NOTARIS (UII Press 2017).[22].
} 
Keberadaan notaris di Indonesia dilandasi karena kebutuhan akan suatu alat bukti yang mengikat selain alat bukti saksi. Notaris berasal dari kata notarius untuk tunggal dan notarii untuk jamak. Notarius merupakan istilah yang digunakan oleh masyarakat Romawi untuk menamai mereka yang melakukan pekerjaan menulis. ${ }^{9}$ Dalam kehidupan sehari-hari kebutuhan akan suatu alat bukti semakin hari semakin penting. Dalam Pasal 1865 BW bahwa setiap orang yang mengaku mempunyai hak harus membuktikan adanya hak tersebut. Alat bukti tertulis tersebut diatas merupakan dalam bentuk rangkaian huruf maupun rangkaian kata menjadi kalimat dan mengandung arti, di Indonesia dikenal dengan sebutan kata "ACTE" sekarang ditulis "AKTA". 10

Kewenangan Notaris didapatkan dari undang-undang, maka dalam Pasal 15 UUJN, kewenangan seorang Notaris dijabarkan. Tak hanya wewenang seorang notaris dalam jabatannya saja, notaris mempunyai wewenang sebagai pejabat umum sebagaimana dalam Pasal 1865 BW yakni membuat akta otentik. Tugas utama Notaris selaku pejabat umum adalah membuat akta otentik dengan cara merelatir dan menkonstatir dari perbuatan hukum pihak (pihak) yang diatur dalam BW dan Kitab Undang-Undang Hukum Dagang (KUHD/ Wetboek van Koophandel). ${ }^{11}$

Notaris berwenang membuat akta otentik mengenai semua perbuatan, perjanjian, dan penetapan yang diharuskan oleh peraturan perundang-undangan dan/atau yang dikehendaki oleh yang berkepentingan untuk dinyatakan dalam akta otentik. Pejabat yang dimaksud dalam Pasal 1868 BW satu-satunya adalah Notaris, walaupun hanya menerangkan apa yang dimaksud dengan "akta otentik", akan tetapi tidak menerangkan apa itu "pegawai umum" juga tidak diterangkan tempat dimana ia berhak atau batas kewenangannya. ${ }^{12}$ Notaris selain merupakan pejabat umum sebagaimana dalam Pasal 1 UUJN, Notaris juga merupakan profesi, hal ini terbukti dalam konsideran menimbang

\footnotetext{
${ }^{9}$ Abdul Ghofur Anshori, Lembaga Kenotariatan Indonesia Perspektif Hukum dan Etika (UII Press 2016).[7].

${ }^{10}$ A.A.Andi Prajitno, Seri A Kewenangan Notaris dan Contoh Bentuk Akta (Perwira Media Nusantara 2018).[5]. (selanjutnya disebut Andi Prayitno 1)

${ }^{11}$ A.A.Andi Prajitno, Op.Cit.[25].

12 ibid.[33].
} 
UUJN pada huruf C dimana notaris merupakan jabatan yang menjalankan "profesi” dan terdapat pula dalam Pasal 1 angka 5 UUJN. Selain itu, hal ini di dukung pula dengan adanya Kode Etik Jabatan Notaris, yang mana kode etik ini dibuat untuk menjadi dasar suatu profesi untuk bertindak, selain itu juga Notaris di katakan sebagai profesi karena untuk menjadi seorang notaris diperlukan pengetahuan dan keterampilan khusus.

Kewenangan notaris dalam tugas dan jabatannya adalah membuat akta otentik. Bentuk dari akta Notaris ini diatur dalam Pasal 38 UUJN. Akta Notaris dikatakan sebagai akta otentik selama pembuatan akta tersebut memenuhi unsur yang ada dalam Pasal 15 ayat (1) UUJN. Selain harus memenuhi unsur yang ada dalam Pasal 15 ayat (1) UUJN, akta notaris yang dibuat itupun harus memenuhi unsur dari syarat sahnya suatu perjanjian sebagaimana yang ada dalam Pasal $1320 \mathrm{BW}$.

Notaris sebagai pejabat umum yang berwenang membuat akta maka terhadap akta yang dibuat oleh nya, notaris tersebut wajib mempertanggung jawabkannya. Terhadap akta yang dibuatnya sesuai dengan Pasal 38 UUJN, yang menjadi tanggung jawab Notaris adalah pada bagian awal akta atau kepala akta dan pada akhir akta atau penutup akta. Pada awal akta tertulis mengenai judul akta, nomor akta, waktu pembuatan akta, dan nama lengkap serta tempat kedudukan notaris nya, dan pada akhir akta atau penutup akta juga menjadi tanggung jawab notaris, karena pada akhir akta ini memuat tentang uraian tetang pembacaan akta sebagaimana Pasal 16 ayat (1) huruf $m$ atau Pasal 16 ayat (7).

Pengangkatan dan pemberhentian notaris diatur dalam UUJN dan diatur lebih lanjut dalam Peraturan Menteri Hukum dan Hak Asasi Manusia Republik Indonesia Nomor 25 tahun 2014 mengenai syarat dan tata cara pengangkatan, perpindahan, pemberhentian dan perpanjangan masa jabatan notaris (selanjutnya di sebut Permen Hukum dan HAM RI no. 25 tahun 2014). Notaris diangkat dan diberhentikan oleh Menteri, hal ini termaktub dalam Pasal 2 UUJN. Pengangkatan notaris tersebut harus memenuhi syarat sebagaimana diatur dalam Pasal 3 UUJN, dan sebelum menjalankan tugas dan wewenang, seorang calon Notaris yang akan diangkat wajib mengucapkan sumpah/janji sebagaimana Pasal 4 UUJN dan dalam Pasal 8 ayat (1) Permen Hukum dan HAM RI no. 25 tahun 2014. 
Wewenang seorang Notaris berasal dari wewenang Atribusi, dengan artian bahwa wewenang seorang notaris berasal dari Undang-Undang, dan pemberian wewenang tersebut ditandai dengan diberikannya surat keputusan pengangkatan yang di keluarkan oleh Menteri Hukum dan Hak Asasi Manusia. Begitu pula dengan pemberhentian seorang notaris dari jabatannya sebagai Notaris ditandai dengan surat keputusan pemberhentian baik pemberhentian dengan hormat maupun pemberhentian dengan tidak hormat dari jabatannya yang dikeluarkan juga oleh Menteri Hukum dan Hak Asasi Manusia.

Sebagaimana dinyatakan dalam UUJN, Notaris berhenti atau diberhentikan dari jabatannya dikarenakan antara lain:

1. Meninggal Dunia;

2. Telah habis masa jabatan;

3. Permintaan sendiri;

4. Tidak mampu secara rohani dan/atau jasmani untuk melaksanakan tugas jabatan notaris secara terus menerus lebih dari 3 (tiga) tahun;

5. Merangkap jabatan sebagaimana dimaksud dalam Pasal 3 huruf g UUJN.

Pasal 66 Permen Menteri Hukum dan HAM No. 25 tahun 2014 terdapat alasan lain seorang notaris dapat berhenti atau diberhentikan dari jabatannya. Notaris dapat dikenakan dua sanksi yakni, pertama, pemberhentian notaris sementara dari jabatannya yang diatur dalam Pasal 9 UUJN dan yang kedua adalah pemberhentian notaris dengan tidak hormat dari jabatannya diatur dalam Pasal 13 UUJN. Pemberhentian dengan tidak hormat ini dilakukan atas usul MPP kepada menteri. MPP dapat menerima laporan dari masyarakat atau usul dari organisasi notaris serta rekomendasi dari dari MPD dan MPW. Usul dari MPP yang diserahkan kepada menteri juga memuat tentang penunjukan notaris lain sebagai pemegang protokol, lalu menteri akan memberhentikan notaris dengan tidak hormat dan menetapkan notaris lain sebagai pemegang protokol dengan mengeluarkan surat keputusan menteri. Selain itu, pemberhentian notaris dengan tidak hormat dapat dikarenakan notaris tersebut dijatuhi pidana penjara berdasarkan putusan pengadilan yang telah memperoleh kekuatan hukum tetap yang diancam pidana penjara 5 (lima) tahun atau lebih. Penunjukan notaris lain sebagai pemegang protokol dan penyerahan serah terima protokol sebagaimana 
dimaksud, maka berlaku ketentuan Pasal 67 Permen Hukum dan HAM RI no. 25 tahun 2014. Apabila seorang notaris berhenti atau diberhentikan dari jabatannya, sejak ditetapkan tanggal keputusan pemberhentian notaris, maka ia tidak lagi berwenang membuat akta. Notaris yang diusulkan untuk diberhentikan dengan tidak hormat, terhadap akta yang dibuatnya masih merupakan akta otentik, karena dengan surat usulan pemberhentian tersebut tidak serta merta bahwa ia telah kehilangan wewenangnya sebagai seorang Notaris. Sama halnya dengan pengangkatan notaris, bahwa pemberhentian notaris pun harus disertai dengan surat keputusan pemberhentian yang dikeluarkan oleh Menteri.

Bila kewenangan seorang notaris dicabut maka Notaris tersebut tidak berwenang lagi untuk membuat akta. Pencabutan kewenangan ini didasari dengan surat keputusan pemberhentian baik dengan hormat atau pun pemberhentian dengan tidak hormat. Apabila notaris tersebut dalam masanya telah di berhentikan dari jabatanya sebagai seorang notaris dan tetap membuat akta, maka akta tersebut bersifat sebagai akta dibawah tangan, dan tidak lagi sebagai akta otentik. Ketika yang bersangkutan mengeluarkan akta dalam hal ia telah diberhentikan sebagai seorang notaris, maka akta tersebut harus dilihat sebagai akta yang bukan dikeluarkan seorang pejabat notaris sehingga akta tersebut merupakan akta di bawah tangan dan pertanggungjawaban terhadap akta dibawah tangan merupakan tanggung jawab pribadi, ia tidak lagi bertanggung jawab secara jabatannya sebagai seorang Notaris.

\section{Kewenangan Majelis Pengawas Notaris Dalam Pemberian Sanksi}

Majelis Pengawas Notaris (selanjutnya disebut MPN) adalah satu institusi yang memiliki tujuan untuk pengawasan terhadap Notaris. Tujuan lain dari pengawasan notaris, bahwa notaris dihadirkan untuk melayani kepentingan masyarakat yang membutuhkan alat bukti berupa akta otentik sesuai permintaan yang bersangkutan kepada notaris, sehingga tanpa adanya masyarakat yang membutuhkan notaris, maka notaris tidak ada gunanya. ${ }^{13}$ Keberadaan MPN ini merupakan pengawasan

${ }^{13}$ Habib Adjie, Memahami: Majelis Pengawas Notaris (MPN) dan Majelis Kehormatan Notaris (MKN) (Refika Aditama 2017).[8]. (selanjutnya disebut Habib Adjie 1) 
bagi kinerja Notaris, agar Notaris dalam menjalankan tugas jabatan profesinya tetap sejalan dengan apa yang dimaksudkan didalam UUJN.

UUJN mengatur mengenai MPN yang fungsinya adalah untuk mengawasi kerja Notaris agar tetap pada jalurnya. Pasal 67 ayat (1) UUJN menentukan bahwa yang melakukan pengawasan terhadap Notaris dilakukan oleh Menteri, yang mana menteri akan membentuk Majelis Pengawas, yakni MPN yang merupakan perpanjangan tangan dari menteri dalam hal pengawasan terhadap notaris.

MajelisPengawas Notaris(MPN)sebagaisatu-satunyainstansiyangberwenang melakukan pengawasan, pemeriksaan dan menjatuhkan sanksi terhadap Notaris, tiap jenjang MPN terdiri dari majelis pengawas (MPD, MPW dan MPP) mempunyai wewenang masing-masing. ${ }^{14}$ Majelis Pengawas Notaris secara umum mempunyai ruang lingkup kewenangan menyelenggarakan sidang untuk memeriksa adanya pelanggaran kode etik notaris atau pelanggaran pelaksanaan jabatan notaris (Pasal 70 uruf a, Pasal 73 ayat (1) huruf a dan b, Pasal 77 huruf a dan b UUJN). ${ }^{15}$

Majelis pengawas sebagaimana yang dimaksud dalam UUJN, pengaturan lebih lanjutnya diatur dalam Peraturan Menteri Hukum dan Hak Asasi Manusia Republik Indonesia Nomor M.02.PR.08.10 Tahun 2004 tentang Tata cara pengangkatan anggota, pemberhentian anggota, susunan organisasi, tata kerja, dan tata cara pemeriksaan Majelis Pengawas Notaris (selanjutnya disebut Permen Hukum dan HAM no. M.02.PR.08.10). Dalam Pasal 1 angka 1 Permen Hukum dan HAM no. M.02.PR.08.10 Majelis Pengawas Notaris adalah suatu badan yang mempunyai kewenangan dan kewajiban untuk melaksanakan pengawasan dan pembinaan tehadap notaris. Pengawasan yang dimaksud adalah kegiatan yang bersifat preventif dan kuratif termasuk kegiatan pembinaan yang dilakukan oleh Majelis Pengawas terhadap Notaris.

Pengawasan yang dilakukan oleh Majelis tidak hanya pelaksanaan tugas jabatan notaris agar sesuai dengan ketentuan UUJN, tapi juga Kode Etik Notaris

\footnotetext{
14 ibid. [11].

15 ibid. [171].
} 
dan tindak tanduk atau perilaku kehidupan notaris yang dapat mencederai keluhuran atau perilaku kehidupan notaris16. Majelis Pengawas Notaris berdasarkan UUJN Pasal 70, Pasal 73 dan Pasal 77 mempunyai ruang lingkup kewenangan menyelenggarakan sidang untuk memeriksa adanya dugaan pelanggaran Kode Etik Notaris atau pelanggaran pelaksanaan jabatan Notaris.

Wewenang dari MPD diatur dalam Pasal 66, Pasal 70 dan Pasal 71 UUJN dan juga dalam Pasal 13 ayat(1) dan(2) Peraturan Menteri Hukum dan HakAsasi Manusia Republik Indonesia Nomor M.02.PR.08.10 Tahun 2004, yang menyatakan bahwa kewenangan MPD lebih pada kewenangan administratif. MPD dapat melakukan pemeriksaan terhadap notaris yang diduga melakukan pelanggaran terhadap UUJN ataupunterhadapKodeEtikNotarisapabilaadalaporandarimasyarakattentangnotaris termaksud dan hasil dari pemeriksaan tersebut yang dilakukan oleh tim pemeriksan akan dibuat kedalam berita acara yang akan dilaporkan kepada MPW.

Wewenang dari Majelis Pengawas Wilayah atau MPW selain diatur dalam UUJN Pasal 73, MPW diatur pula dalam dalam Peraturan Menteri Hukum dan Hak Asasi Manusia Republik Indonesia Nomor M.02.PR.08.10 Tahun 2004, dan Keputusan Menteri Hukum dan Hak Asasi Manusia Republik Nomor M. 39-PW.07.10 Tahun 2004. Sedangkan untuk MPP, diatur dalam Pasal 77 UUJN dan diatur pula sebagaimana tentang MPD dan MPW pada Peraturan Menteri Hukum dan Hak Asasi Manusia Republik Indonesia Nomor M.02.PR.08.10 Tahun 2004, dan Keputusan Menteri Hukum dan Hak Asasi Manusia Republik Nomor M. 39-PW.07.10 Tahun 2004. Kewenangan Majelis Pengawas Notaris, sebagaimana Pasal 73 UUJN tersebut dalam menjatuhkan sanksi pada Notaris pada dasarnya tidak semua Majelis Pengawas Notaris memiliki wewenang untuk menjatuhkan sanksi, antara lain:

1. MPD tidak mempunyai kewenangan untuk menjatuhkan sanksi apapun;

2. MPW dapat menjatuhkan sanksi teguran dan sanksi tertulis;

3. MPP dapat menjatuhkan sanksi terbatas.

16 ibid.[22]. 
Sebagaimana dalam Pasal 77 UUJN menentukan bahwa MPP berwenang menjatuhkan sanksi pemberhentian sementara. Sanksi seperti ini merupakan masa menunggu dalam jangka waktu tertentu sebelum dijatuhkan sanksi yang lain, seperti sanksi pemberhentian dengan hormat dari jabatan Notaris. Selain itu MPP berwenang untuk mengusulkan :

a) Pemberian sanksi berupa pemberhentian dengan tidak hormat dari jabatannya kepada Menteri (Pasal 77 huruf d UUJN);

b) Pemberian sanksi berupa pemberhentian tidak hormat dari jabatannya dengan alasan tertentu (Pasal 12 UUJN). ${ }^{17}$

Menteri mempunyai wewenang dalam melakukan pengawasan dan pembinaan terhadap Notaris, yang dalam pelaksanaan hal ini Menteri di bantu oleh Majelis Pengawasan Notaris (MPN) dan Majelis Kehormatan Notaris (MKN) melalui kewenangannya masing-masing. Menteri mempunyai tugas membantu Presiden dalam penyelengaraan sebagian urusan pemerintah. Maka dari itu kewenangan pengawasan dan pemeriksaan serta pembinaan terhadap Notaris sesungguhnya ada pada pemerintah.

\section{Tanggung Jawab Notaris Terhadap Akta Yang Dibuat Oleh dan Dihadapannya}

Tanggung jawab merupakan kewajiban dari seseorang untuk menanggung sesuatu baik yang dilakukannya atau tidak. Saat seseorang telah memiliki kewenangan untuk menjalankan tugas dan kewajiban seorang Notaris, maka pada saat itu pula ia harus bertanggung jawab atas akta dan segala hal yang dilakukannya yang terkait dengan tugas jabatan dan profesinya, termasuk bertanggung jawab atas perbuatan karyawan kantor notaris yang berhubungan dengan pembuatan akta, karena dasarnya akta notaris adalah merupakan tanggung jawab dari notaris yang membuat akta tersebut. Baik asas maupun kewajiban dari seorang notaris yang tertera didalam UUJN dan Kode Etik Notaris berlaku agar Notaris tidak melakukan kesalahan atau kelalaian dalam menjalankan tugasnya sebagai Notaris, baik secara pribadi atau secara jabatannya.

${ }_{17}$ Habib Adji, Memahami : Majelis Pengawas Notaris (MPN) dan Majelis Kehormatan Notaris (MKN) (Refika Aditama 2017).[26]. (selanjutnya disebut Adji, Habib, 2) 
Akta otentik ini merupakan salah satu jenis alat pembuktian sebagaimana jenis alat bukti yang diatur dalam Pasal 1866 BW. Arti akta otentik mempunyai kekuatan pembuktian yang sempurna dapat pula ditentukan bahwa siapa pun terikat dengan akta tersebut, sepanjang tidak bisa dibuktikan bukti sebaliknya berdasarkan putusan pengadilan yang mempunyai kekuatan hukum tetap. ${ }^{18}$ Artinya bahwa akta otentik ini mempunyai kekuatan pembuktian yang sempurna, sepanjang pihak yang berkepentingan tidak membuktikan hal sebaliknya, karena pihak yang berkepentingan dapat membuktikan hal yang sebaliknya di hadapan persidangan pengadilan. Bahwa akta otentik yang juga merupakan produk dari notaris merupakan akta yang sempurna dan terpenuh maka kesempurnaan dari akta otentik ini akta tersebut harus dilihat apa adanya tidak perlu dinilai atau ditafsirkan lain.

Alat bukti tertulis sebagaimana dimaksud terbagi mejadi dua yakni, Akta otentik dan Akta di bawah tangan, yang mana kekuatan pembuktian keduanya pun berbeda. Akta otentik sebagaimana yang telah dijelaskan sebelumnya memiliki kekuatan pembuktian yang sempurna. Sedangkan akta dibawah tangan adalah surat atau tulisan yang dibuat oleh para pihak tanpa ada campur tangan pejabat umum dan peraturan perundang-undangan tidak mengharuskannya. ${ }^{19}$ Akta dibawah tangan mempunyai kekuatan pembuktian sepanjang para pihak mengakuinya atau tidak ada penyangkalan dari salah satu pihak. ${ }^{20}$ Jadi, sebagaimana dalam Pasal $1875 \mathrm{BW}$ bahwa selama akta di bawah tangan tersebut tidak disangkal keberadaannya maka akta tersebut memiliki kekuatan pembuktian sempurna sebagaimana akta otentik, namun apabila salah satu pihak menyangkal keberadaan akta tersebut, maka pihak yang menyangkal itu yang harus membuktikan, dan penilaian pembuktian akta dibawah tangan tersebut akan di serahkan pada hakim.

Akta Otentik, konkretnya dibuat sengaja untuk menjadi alat bukti bagi para pihak yang menghendakinya. Berdasarkan ketentuan Pasal 1868 BW, dapat

\footnotetext{
${ }^{18}$ Habib Adjie, Kebatalan dan Pembatalan Akta Notaris (Refika Aditama 2015).[6]. (selanjutnya disebut sebagai Habib Adjie 3)

${ }^{19} \mathrm{https}$ //www.legalakses.com/akta-otentik-dan-akta-di-bawah-tangan/, diakses pada tanggal 08 Agustus 2018, pukul 19.28 WIB (Waktu Indonesia Barat).

${ }^{20}$ Oemar Mochtar, Dasar-Dasar Teknik Pembuatan Akta (Airlangga University Press 2017). [15].
} 
diklasifikasikan menjadi 2 (dua), yaitu: Pertama akta yang dibuat "oleh" pegawai umum. Akta jenis ini lazim disebut dengan istilah "akta pejabat", "acte ambtelijk, "relaas acta" atau "procesverbaal acte". Kedua, akta yang dibuat "dihadapan" pegawai umum. Akta ini lazim disebut dengan istilah, "akta partai" atau "Acte Partij". ${ }^{21}$ Akta relaas atau berita acara adalah akta yang dibuat oleh Notaris dan Akta pihak atau Akta Partij adalah akta yang dibuat dihadapan Notaris.

Akta dibawah tangan pada dasarnya pengertiannya adalah sebuah akta yang dibuat tidak oleh atau dihadapan pejabat umum. Kekuatan pembuktian akta dibawah tangan tidak sesempurna akta otentik, dalam artian bahwa, akta dibawah tangan dapat disamakan kekuatan pembuktiannya dengan akta otentik selama para pihak yang membuat akta tersebut mengakui keberadaan dari akta dibawah tangan tersebut. Sejauh diakui maka akta dibawah tangan mempunyai sifat pembuktian yang sempurna sebagaimana akta otentik, namun selama akta dibawah tangan disangkal keberadaannya, maka para pihak harus membuktikan kebenaran dari isi akta tersebut. Akta Notaris dikatakan sebagai akta otentik selama pembuatan akta tersebut memenuhi unsur yang ada dalam Pasal 15 ayat (1) UUJN. Selain harus memenuhi unsur yang ada dalam Pasal 15 ayat (1) UUJN, akta notaris yang dibuat itupun harus memenuhi unsur dari syarat sahnya suatu perjanjian sebagaimana yang ada dalam Pasal 1320 BW.

Tanggung jawab notaris terhadap akta yang dibuatnya ada pada awal atau kepala akta dan akhir akta. Pada awal akta menjadi tanggung jawab notaris karena awal akta berisikan mengenai keterangan hari, tanggal dan jam dimana akta tersebut dibuat dan juga nama serta kedudukan dari notaris pembuat akta itu, hal ini menunjukkan kepastian waktu pembuatan akta dan menunjukan apakah pembuatan akta notaris tersebut masih termasuk kedalam wilayah jabatan dari notaris yang membuatnya. Sedangkan pada akhir akta merupakan tanggung jawab notaris juga karena pada akhir atau penutup akta mencantumkan mengenai pembacaan akta dan dimana akta tersebut diselesaikan.

${ }^{21}$ Lilik Mulyadi, Hukum Acara Perdata menurut Teori da Praktik Peradilan Indonesia (Penerbit Djambatan, Edisi Revisi 2002).[162]. 
Akta notaris yang merupakan alat bukti dengan kekuatan pembuktian yang sempurna, jika seluruh prosedur atau tata cara pembuatan akta sebagaimana yang telah disebut didalam peraturan perundang-undangan terpenuhi, jika ada salah satu prosedur atau tata cara tersebut tidak terpenuhi dan prosedur yang tidak terpenuhi tersebut dapat dibuktikan, maka akta tersebut didalam proses pengadilan dapat dinyatakan sebagai akta dibawah tangan dan nilai pembuktiannya akan diserahkan pada hakim. Akta Notaris sebagai akta otentik selain mempunyai nilai sebagai alat pembuktian terpenuh dan sempurna, juga memiliki nilai pembuktian lainnya. Ada 3 (tiga) nilai pembuktian dari akta otentik, antara lain:

1. Kekuatan pembuktian lahiriah;

2. Kekuatan pembuktian formil;

3. Kekuatan pembuktian materiil.

Terdapat 2 (dua) macam pertanggung jawaban berdasarkan kesalahan (based on fault) dan pertanggung jawaban mutlak (absolute responsibility). ${ }^{22}$ Pertanggungjawaban mempunyai dasar dimana adanya suatu hal yang menimbulkan hak hukum terhadap seseorang yang dapat menuntut orang lain yang dapat melahirkan kewajiban hukum dari orang tersebut untuk memberikan pertanggung jawabannya.

Pemberian sanksi terhadap notaris tidak hanya terbatas pada UUJN dan Kode Etik Notaris saja yang jenis sanksinya berupa sanksi administrasi. Dalam Pasal 65 UUJN bahwa setiap akta notaris menjadi tanggungjawab dari Notaris, Notaris Pengganti, dan Pejabat Sementara Notaris bertanggung jawab atas setiap akta yang dibuatnya meskipun protokol notaris telah diserahkan atau dipindahkan kepada pihak penyimpan protokol notaris. Pasal UUJN ini berarti bahwa walau seorang notaris telah pensiun maka ia tetap bertanggung jawab terhadap akta yang telah dibuatnya. Terhadap akta Notaris yang diuraikan dalam UUJN yang mempunyai sifat sebagai akta otentik. Akta Notaris ini juga terbagi atas 2 (dua) macam akta, yakni Akta pihak (partij acte) dan Akta berita acara (relaas acte). Terdapat perbedaan tanggung jawab terhadap kedua jenis akta tersebut.

\footnotetext{
${ }^{22}$ M. Luthfan Hadi Darus, Loc.Cit.[47].
} 


\section{Tanggung Jawab Notaris yang Diberhentikan Sementara dan Dalam Proses Diusulkan Untuk Diberhentikan Dengan Tidak Hormat}

Notaris dapat berhenti atau diberhentikan, dengan melihat alasan-alasan yang ada dalam UUJN dan Permen Hukum dan HAM RI no. 25 tahun 2014 mengenai syarat dan tata cara pengangkatan, perpindahan, pemberhentian dan perpanjangan masa jabatan notaris. Alasan - alasan tersebut menyebabkan Notaris berhenti atau diberhentikan. Pemberhentian Notaris sendiri terbagi atas 2 (dua) yakni, Pemberhentian sementara sebagaimana pasal 9 UUJN dan Pemberhentian dengan tidak hormat terhadap notaris sebagaimana pasal 13 UUJN. Terhadap kedua pemberhentian tersebut terdapat perbedaan kewenangan dan kewajiban terhadap notaris yang bersangkutan.

Pada pasal 9 UUJN yakni mengenai Pemberhentian sementara, jangka waktu pemberhentian tersebut yakni pemberhentian sementara selama 3 (tiga) bulan hingga 6 (enam) bulan sebagaimana dalam pasal 73 UUJN. Pemberhentian sementara atau skorsing ini diberikan kepada Notaris oleh MPW. Pemberhentian sementara ini berarti bahwa selama 3 (tiga) bulan hingga 6 (enam) bulan tergantung pada keputusan dari MPW bahwa Notaris tersebut tidak berwenang untuk membuat akta. Selama masa skorsing ini Notaris tidak diperbolehkan untuk membuat akta otentik. Skorsing selama 3 (bulan) ini tidak diperlukan untuk penyerahan protokol notaris kepada notaris pengganti pemegang protokol. Karena untuk penyerahan protokol akan memakan waktu yang pajang, hanya saja notaris selama 3 (tiga) bulan tidak boleh menjalankan tugas dan wewenangnya sebagai notaris. Pada skorsing selama 6 bulan, Notaris wajib menentukan notaris pengganti pemegang protokol dan mengajukannya kepada MPD, atau apabila notaris tersebut tidak menunjuk notaris pengganti, maka MPD akan menunjuk notaris lain sebagai notaris pengganti pemegang protokol. Terhadap notaris yang di skorsing, tanggung jawab yang melekat terhadap dirinya adalah tanggung jawab pribadi dan tidak dalam jabatannya sebagai seorang notaris walaupun ia masih seorang notaris, namun terhadap kewenangan notaris, ia tidak berwenang untuk menjalankan kewenangan notaris hingga masa skorsingnya selesai atau di cabut. 
Apabila notaris tersebut di berikan sanksi skorsing atau pemberhentian sementara dan juga sementara dalam proses diusulkan untuk diberhentikan dengan tidak hormat, maka terhadap jabatannya, ia tidak lagi berwenang untuk membuat akta otentik, dan tanggung jawabnya pun terhadap atas tindakannya maka ia harus bertanggung jawab secara pribadi, dan apabila tindakannya tersebut merugikan pihak ketiga maka ia dapat bertanggung jawab secara pidana.

\section{Sanksi Terhadap Notaris}

Apabila Notaris terbukti bersalah, maka Notaris dapat dikenakan sanksi administrasi, sanksi perdata, sanksi pidana atau sanksi kombinasi. Namun pada dasarnya tidak semua apa yang dilakukan oleh Notaris menjadi tanggungjawab dari Notaris, hukum sendiri memberikan batasan terhadap tanggungjawab yang dibebankan kepada Notaris, tidak semua kerugian terhadap pihak ketiga menjadi tanggung gugat ataupun tanggungjawab dari Notaris.

Sanksi sebagaimana dalam Pasal 84 dan Pasal 85 UUJN terdapat 2 (dua) macam sanksi antara lain adalah Sanksi perdata yang ada dalam Pasal 84 dan sanksi administrasi dalam Pasal 85. Dalam hukum, sanksi merupakan suatu tindakan yang digunakan untuk seseorang agar menepati perjanjian atau mentaati suatu ketentuan perundang-undangan. Notaris sebagai pejabat umum yang berwenang untuk membuat akta, terhadap kewenangannya tersebut maka Notaris dibebani tanggungjawab dalam pembuatan akta otentik yang tidak sesuai dengan ketentuan dan peraturan perundang-undangan yang berlaku. Berkaitan dengan wewenang tersebut, jika notaris melakukan tindakan diluar wewenang yang telah ditentukan, maka akta Notaris tersebut tidak mengikat secara hukum atau tidak dapat dilaksanakan (nonexecutable). ${ }^{23}$

Akta Notaris, apabila melanggar ketentuan tertentu, akan terdegradasi nilai pembuktiannya menjadi mempunyai kekuatan pembuktian sebagai akta dibawah tangan. ${ }^{24}$ Pasal 84 UUJN telah menyebutkan mengenai sanksi perdata, dalam Pasal

\footnotetext{
${ }^{23}$ M. Lutfhan Hadi Darus, Op.Cit. [64].

${ }^{24}$ Sjaifurrachman, Op.Cit.[195].
} 
tersebut 2 (dua) jenis sanksi jika Notaris yang bersangkutan melakukan pelanggaran terhadap Pasal-Pasal tertentu sebagaimana telah disebutkan dalam Pasal 84 UUJN, sanksi tersebut yakni:

1. suatu akta hanya mempunyai kekuatan pembuktian sebagai akta dibawah tangan;

2. suatu akta menjadi batal demi hukum;

Terhadap 2 (dua) jenis sanksi tersebut dapat menjadi alasan bagi pihak yang menderita kerugian untuk menuntut penggantian biaya, ganti rugi, dan bunga kepada Notaris.

Akta dibawah tangan ini mempunyai kekuatan pembuktian sebagai pembuktian smepurna selama para pihak mengakuinya. Sedangkan apabila suatu akta menjadi batal demi hukum, maka akta tersebut sejka awal dianggap tidak pernah ada dan oleh karena nya perbuatan hukum yang dilakukan dianggap tidak pernah terjadi. Terhadap akta yang batal demi hukum, sesuatu yang dianggap tidak pernah ada tidak dapat dijadikan dasar suatu tuntutan dalam bentuk penggantian biaya, ganti rugi dan bunga. Akta Notaris yang batal demi hukum memiliki batasan selama akta tersebut tidak memenuhi syarat objektif sebagaimana dalam Pasal 1320 BW yakni tentang obyek tertentu dan kausa yang terlarang, maka perjanjian tersebut batal demi hukum.

Perbuatan seseorang dikatakan sebagai perbuatan pidana apabila perbuatan yang dilakukan tersebut telah tercantum dalam undang-undang, karenanya dalam pidana dikenal dengan asas legalitas. Dengan kata lain untuk mengetahui perbuatan seseotrang tersebut dikatakan perbuatan pidana maka harus melihat peraturan perundang-undangan yang ada. Secara khusus pelangaran pidana dalam UUJN ataupun dalam kode etik tidak diatur secara khusus, namun tidak berarti bahwa Notaris tidak dapat dijatuhi sanksi pidana. Penjatuhan sanksi pidana terhadap Notaris dapat dilakukan sepanjang batasan-batasan sebagaimana yang disebutkan tersebut dilanggar, dalam artian tidak hanya batasan yang ada dalam UUJN dan kode etik notaris saja yang dilanggar, tetapi unsur-unsur dalam pidana juga dilanggar. Menurut Pasal 13 UUJN, apabila seorang Notaris dijatuhi hukuman pidana berdasarkan putusan pengadilan dengan ancaman pidana lebih dari 5 tahun, 
maka Notaris yang bersangkutan dapat diberhentikan dengan tidak hormat dari jabatannya sebagai Notaris.

Selain sanksi perdata yang dapat dijatuhkan pada Notaris sebagaimana Pasal 84 UUJN, ada juga sanksi administrasi yang dapat diberikan pada Notaris yang terbukti melakukan pelanggaran terhadap UUJN dan Kode Etik Notaris yang tercantum dalam Pasal 85 UUJN, dalam Pasal 85 UUJN ada 5 (lima) macam sanksi administrasi, antara lain:

1. Teguran lisan;

2. Teguran tertulis;

3. Pemberhentian sementara;

4. Pemberhentian dengan hormat;

5. Pemberhentian dengan tidak hormat.

Sanksi notaris karena melanggar ketentuan-ketentuan sebagaimana tersebut dalam Pasal 85 UUJN merupakan sanksi internal, yaitu sanksi terhadap Notaris dalam melaksanakan tugas jabatannya tidak melakukan serangkaian tindakan tertib pelaksanaan tugas jabatannya, kerja notaris yang harus dilakukan untuk kepentingan notaris sendiri. ${ }^{25}$ Dalam Pasal 85 UUJN pemberian sanksi pemberhentian baik pemberhentian sementara, pemberhentian dengan hormat hingga pemberhentian dengan tidak hormat, tentunya harus memperhatikan tingkat berat atau ringannya pelanggran yang dilakukan oleh seorang Notaris. UUJN hanya mengatur tentang sanksi perdata dan sanksi administrasi, kedua sanksi ini tidak dapat dikumulasikan atau di gabungkan secara bersama-sama, karena kedua sanksi ini dijatuhkan apabila melakukan jenis pelanggaran berbeda sebagaimana dalam Pasal 84 dan Pasal 85 UUJN. Adanya berbagai jenis sanksi yang dapat dijatuhkan pada Notaris apabila terbukti melakukan pelanggaran hal ini berkaitan dengan sanksi kombinasi atau sanksi kumulatif. Sanksi-sanksi tersebut berdiri sendiri, bahwa ada unsur-unsur tertentu dari pelanggaran Notaris yang menyebabkan Notaris dijatuhi suatu sanksi, namun alasan-alasan atau unsur-unsur tersebutlah yang menyebabkan seorang Notaris dapat dijatuhi sanksi kombinasi atau sanksi kumulatif.

${ }^{25}$ Sjaifurrachman, Op.Cit.[205]. 


\section{Kesimpulan}

Notaris yang diusulkan untuk diberhentikan dengan tidak hormat, terhadap akta yang dibuat olehnya masih merupakan akta otentik, karena dengan surat usulan pemberhentian tersebut tidak serta merta bahwa ia telah kehilangan wewenangnya sebagai seorang Notaris. Pemberhentian dengan tidak hormat ini dilakukan terlebih dahulu atas adanya usulan yang diberikan oleh MPP. Apabila seorang notaris berhenti atau diberhentikan dari jabatannya, sejak ditetapkan tanggal keputusan pemberhentian notaris yang dikeluarkan oleh menteri, maka ia tidak berwenang lagi membuat akta. Konsekuensi hukum yang harus diterimanya adalah tidak lagi melekat pada dirinya status sebagai notaris yang mana ia tidak dapat lagi mengeluarkan akta otentik atas nama jabatannya selaku notaris. Meskipun dalam putusan MPP notaris tersebut dijatuhi sanksi pemberhentian dengan tidak hormat, dalam jabatannya ia masih berwenang untuk melaksanakan tugas dan jabatan sebagai Notaris, Notaris tersebut tetap masih berwenang untuk melaksanakan tugas dan jabatannya sebagai seorang Notaris, yakni membuat akta otentik.

Akta Notaris merupakan akta otentik mempunyai kesempurnaan sebagai alat bukti. Bentuk akta notaris sebagaimana Pasal 38 UUJN, terdiri atas 3 bagian yakni, awal akta atau kepala akta, badan akta atau isi akta dan akhir atau penutup akta. Tanggung jawab dari notaris terhadap akta yang dibuatnya tersebut ada pada awal akta dan akhir akta. Notaris dalam menjalankan tugas dan jabatannya harus bertanggungjawab terhadap apa yang dilakukan. Kesalahan atau kelalaian yang dilakukan oleh karyawan kantor notaris yang berhubungan dengan akta atau berhubungan Notaris dalam jabatannya juga merupakan tanggung jawab dari notaris tersebut. Dapat dikatakan bahwa prinsip tanggungjawab dalam profesi notaris merupakan tanggung jawab mutlak atau strict liability. Bahkan hingga notaris tersebut berhenti atau pensiun dari jabatannya, sekalipun tanggung jawabnya terhadap akta yang dibuatnya selama menjabat tetap masih melekat pada dirinya. 


\section{Daftar Bacaan}

\section{Buku}

A.A.Andi Prajitno, Seri A Kewenangan Notaris dan Contoh Bentuk Akta (Perwira Media Nusantara 2018).

Abdul Ghofur Anshori, Lembaga Kenotariatan Indonesia Perspektif Hukum dan Etika (UII Press Yogyakarta 2016).

Abintoro Prakoso, Etika Profesi Hukum (LaksBang Justitia 2015).

Freddy Haris, Notaris Indonesia (PT. Lintas Cetak Djaja 2017).

Habib Adji, Memahami : Majelis Pengawas Notaris (MPN) dan Majelis Kehormatan Notaris (MKN) (Refika Aditama 2017).

Habib Adji, Hukum Notaris Indonesia; Tafsir Tematik terhadap UU no. 30 Tahun 2004 Tentang Jabatan Notaris (Refika Aditama 2014).

Habib Adji, Kebatalan dan Pembatalan Akta Notaris (Refika Aditama 2015).

HR. Ridwan, Hukum Administrasi Negara (Raja Grafindo Persada 2006).

Lilik Mulyadi, Hukum Acara Perdata menurut Teori dan Praktik Peradilan Indonesia (Penerbit Djambatan, Edisi Revisi 2002).

M. Luthfan Hadi Darus, Hukum Notariat Dan Tanggungjawab JABATAN NOTARIS (UII Press 2017).

Oemar Mochtar, Dasar-Dasar Teknik Pembuatan Akta (Airlangga University Press 2017).

Sjaifurrachman, Aspek Pertanggun jawaban Notaris dalam Pembuatan Akta (CV. Mandar Maju 2011).

\section{Laman}

https://www.legalakses.com/akta-otentik-dan-akta-di-bawah-tangan/, diakses pada tanggal 08 Agustus 2018, pukul 19.28 WIB (Waktu Indonesia Barat).

http://www.borneonews.co.id/berita/26990-inilah-kisah-menyerobot-sahamperusahaan, diunduh pada tanggal 01 Maret 2017, pukul 20.52 WIB (Waktu Indonesia Barat) 


\section{Karya Ilmiah}

Imelda Mouly Irianty, Tinjauan Yuridis Mengenai Notaris Yang Cuti Diangkat Sebagai Pejabat Negara, (Tesis, Magister Kenotariatan, Universitas Indonesia, Semarang, 2010)

HOW TO CITE: Selly Yashinta Theresa Laseduw, 'Kekuatan Pembuktian Akta Notaris Yang Dibuat Oleh Notaris Yang Sedang Diusulkan Untuk Diberhentikan Dengan Tidak Hormat' (2019) Vol. 2 No. 1 Media Iuris. 
--Halaman ini sengaja dikosongkan-- 